\title{
有機結晶における新機能物性開拓
}

一 $\pi$ 電子と水素の協奏一

\section{Development of novel functional properties of organic crystals in concert of $\pi$-electrons and hydrogens}

\author{
森 初果
}

Hatsumi Mori

\begin{abstract}
Organic functional crystals with novel $\pi$-electronic states such as (super)conductivity, (anti-/ferro)magnetism, etc. have been vigorously developed. On the other hand, researches of hydrogen-related functionalities such as (anti-/ferro) electrics, proton (super)conductivity, etc. have been also extensively performed. In this article, the novel $\pi$-electronhydrogen concerted organic materials and their functionalities are introduced. This phenomenon with dynamically coupled $\pi$ electron-hydrogen might be related to biochemical cascade reactions and applicable to novel organic surface and devices.
\end{abstract}

Keywords: organic functional crystals, hydrogen bond, $\pi$-electronic functionality, hydrogen-related functionality, $\pi$-electron-hydrogen concerted functionality

\section{1.はじめに}

$\pi$ 電子系分子からなる分子性機能物質の研究は, 近年飛 躍的な発展を遂げており，伝導性，磁性，誘電性，および 光, 電場などの外場応答性, そしてその複合機能性など, 精力的な物質開発および機能物性研究が進められている ${ }^{1-4}$ 。 筆者らはこれまで, 有機結晶中において, この $\pi$ 電子集団 の競合・協奏による新たな伝導性, 磁性を中心とした電子 機能を探求してきた ${ }^{5-9}$ 。さらに最近，この $\pi$ 電子の次に軽
い粒子として水素，およびそのイオンであるプロトンにも 注目し，この $\pi$ 電子と，水素抢よびプロトンが静的拉よび 動的に協奏する純有機結晶を開発し, 新しい機能物性をい くつか見出したのでここに紹介する ${ }^{10-19}$ 。

まず，新たな $\pi$ 電子機能を求めた物質開発として, Figure 1（a）のように, 有機分子を設計・合成して二量化配列様 式を上手く制御したところ, 結晶中 $[\beta$-(meso-DMBEDT$\mathrm{TTF})_{2} \mathrm{PF}_{6}$, 分子間の $\pi$ 電子同士のクーロン斥力で, チェッ $\pi$-electronic molecular functional materials

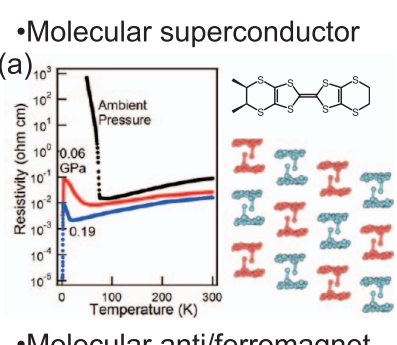

-Molecular anti/ferromagnet
- Molecular non-linear conduction by electric field

(b)

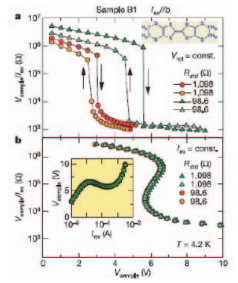

\section{Hydrogen-related molecular} functional materials

-Molecular (super)proton conductor

(c)

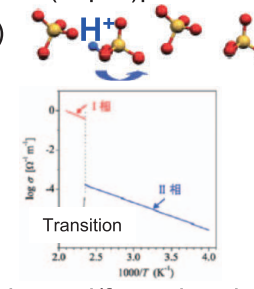

-Molecular anti/ferroelectrics

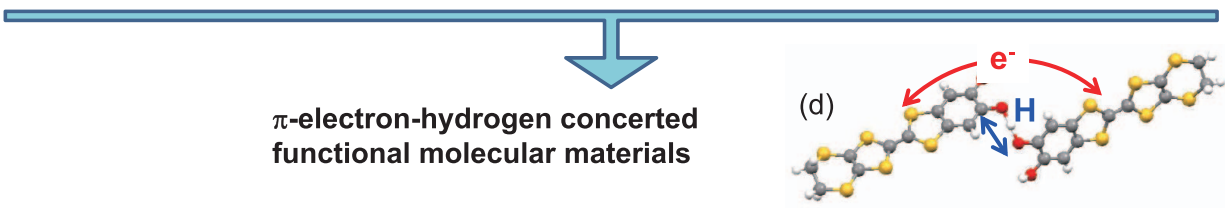

Figure 1. The $\pi$-electronic molecular functional materials, (a) and (b), and the hydrogen-related molecular functional materials, (c), have been studied independently. The dynamic $\pi$-electron-hydrogen concerted functional materials, (d), developed recently are introduced in this article. 
カボード型模様をした $\pi$ 電子の結晶化（局在化）が起きる ことが明らかになった6。さらに，この結晶に圧力をかけ ると, $\pi$ 電子の局在性と遍歴性が競合して新たに超伝導相 が出現することを見出した 5,8 。また，（b）のように，三角 格子上でクーロン斥力がフラストレートした有機結晶 $\left[\theta-(\mathrm{BEDT}-\mathrm{TTF})_{2} \mathrm{CsCo}(\mathrm{SCN})_{4}\right]$ では，異なる模様を示す 2 種 類の $\pi$ 電子の結晶が共存・競合する。その有機結晶に外場 として電圧を印加すると, 結晶化した電子水が流水のよう に壊れて流れ，たった $3 \mathrm{~V} て ゙ 3$ 桁以上の抵抗が減少する大 きな非線形伝導, つまりスイッチング現象が起こる。さら に高抵抗と低抵抗の 2 状態間を電場で制御すると, 直流電 圧一交流電流発振を観測した 9 。このように，有機結晶中 の $\pi$ 電子集団の競合・協奏により, 局在性と遍歴性が競合 する舞台で, 圧力や電場などの外場応答として超伝導や非 線形伝導など新たな電子機能性が出現することを見出して きた ${ }^{5-9}$ 。

上記のような $\pi$ 電子機能とは独立に, 水素が関与した分 子機能物性も研究されている。例えば, Figure 1 (c) のよ うに, $\mathrm{SO}_{4}{ }^{2-}$ が水素結合で連結して 1 次元鎖を形成してい る $\mathrm{CsHSO}_{4}$ の固体中では, 水素イオンであるプロトンの拡 散が調べられている。この系では $150^{\circ} \mathrm{C} て ゙$ 超プロトン伝導 が起こり, 伝導率は約 3 桁程度急増する ${ }^{20}$ 。この高温相で は，隣の $\mathrm{SO}_{4}{ }^{2-}$ イオンヘプロトンを受け渡すために，この アニオンの早い回転が重要な役割を果たすという NMRの 観測結果があり, 分子イオン運動と関係するプロトン伝導 として興味深い ${ }^{21}$ 。

このように, $\pi$ 電子機能と水素が関係する機能物性は, こ れまで各々独立に調べられてきた。そこで筆者らは， $\pi$ 電 子と水素が動的に協奏して起こる新しい機能性の開拓を目 指して物質開発研究を進めたところ, Figure 1 (d) の $\pi$ 電 子一水素協奏系でいくつかの新しい機能物性 ${ }^{10-19}$ が見出さ れたので本稿で紹介する $22-25$ 。

\section{2. 水素における協奏機能物性}

「水素結合」の名付け親はポーリングである。彼は, 1931 年, $[\mathrm{F}: \mathrm{H}: \mathrm{F}]^{-}$の非共有結合を説明するときに, “hydrogen bond” と初めて記述した ${ }^{26,27}$ 。水素結合では，水素原子が 2 つ以上の原子と結合を作っており，ここでは O..H..O 結合 を考える。この水素結合を作る非共有電子対の相対位置, つまり水素および酸素周りの電子分布により, $\mathrm{H}$ は水素あ るいはプロトン， O は酸素あるいはアニオンとなるが，こ こでは水素（H）および酸素（O）と表記する。

これまで,この水素結合の強さと酸素原子間の距離 $\left(R_{\mathrm{OO}}\right)$ および $\mathrm{OH}$ の伸縮振動に相関があることが調べられ ている ${ }^{26,27}$ 。有機および無機物質で, O..O $\left(R_{\mathrm{OO}}\right)$ 間が $2.90-$ $2.70 \AA$ の場合, $\mathrm{OH}$ 伸縮振動も $R_{\mathrm{OO}}$ の減少に伴い, 3500 か ら $3200 \mathrm{~cm}^{-1}$ へと緩やかに減少する「弱い水素結合」であ り, 2.70-2.60 ̊ では 3200 から $2700 \mathrm{~cm}^{-1}$ へと減少率が増す
「中程度の水素結合」となり，2.60-2.40 ̊ では $2700 \mathrm{~cm}^{-1}$ から $700 \mathrm{~cm}^{-1}$ へと劇的に急減する「強い水素結合」に分類 される ${ }^{26}$ 。特に「強い水素結合」の場合, Figure 2 に示す ように, O..H..O 内で水素を移動させた時のポテンシャルエ ネルギーカーブの形状は， $R_{\mathrm{OO}}$ の長い方から (c) 非対称型 のダブルミニマム，（b）対称型のダブルミニマム，（a）対 称型のシングルミニマムと大きく変化する。その中でも, (b) 対称型のダブルミニマムを持つ水素結合では重水素効 果が大きく，O..H..Oを O..D..Oにすると $R_{\mathrm{OO}}$ が最高で 0.027 Å長くなり, 幾何学的効果あるいは Ubbelohde 効果と呼ば れている ${ }^{28,29}$ 。その結果, O..H..O より O..D..Oの方がダブ ルミニマムポテンシャルエネルギーの障壁は深くなる。ま た，重水素に比べ水素の方がゼロ点振動のエネルギーが高 いという量子効果もある。この幾何学的効果と量子的効果 により，協奏的な水素の機能物性である反 / 強誘電相転移

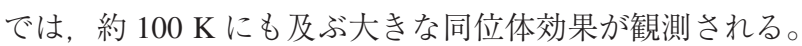

Figure 3 で示すように, 2 つの $\mathrm{SO}_{4}{ }^{2-}$ 四面体が O..H(D)..O で水素結合し，水素結合ユニットとなった $\mathrm{K}_{3} \mathrm{D}_{1-\mathrm{x}} \mathrm{H}_{\mathrm{x}}\left(\mathrm{SO}_{4}\right)_{2}$ $[x=1,0]$ は, 0 次元の水素結合系である。 $R_{\mathrm{OO}}$ は水素体の $\mathrm{K}_{3} \mathrm{H}\left(\mathrm{SO}_{4}\right)_{2}$ で 2.493(1) $\mathrm{A}$, 重水素体 $\mathrm{K}_{3} \mathrm{D}\left(\mathrm{SO}_{4}\right)_{2}$ で 2.519(1) $\AA$ と, 重水素体の方が $\Delta R_{\mathrm{OO}}=0.026 \AA$ 長く, 大きな幾何学 的効果を示す。そのため, 重水素体は室温でより梁いダブ ルミニマムポテンシャルエネルギーを有し, さらに, 重水 素体のゼロ点振動エネルギーは，水素体より低いため，高 温では熱的ホッピングでポテンシャルエネルギー障壁を超 えているが，低温では越えられなくなり，重水素原子が協 奏的に偏って非対称ポテンシャルエネルギーを作って固体 中で揃い， $85 \mathrm{~K}$ で反強誘電相転移を起こす。一方水素体は, 幾何学的効果のため重水素体より浅いダブルミニマムポテ ンシャルエネルギーを有し，より高いゼロ点振動エネル ギーの量子的な効果も加わり, 対称的なポテンシャルエネ ルギーを低温まで保ち，相転移のない量子常誘電状態とな る。このように, 同位体効果で水素体より重水素体の方が $100 \mathrm{~K}$ 近く転移温度が上がるのは驚くべきことであるが, 誘 電体では普通に観測されており，超伝導体や強磁性体など 電子物性では見られない現象である。混晶では，常誘電相 と反強誘電相が競合し， $x_{\mathrm{c}}=0.66$ で臨界的な振る舞いが見

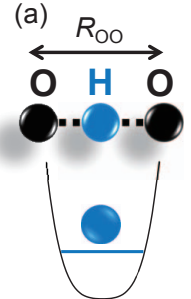

$R_{\mathrm{OO}} \sim 2.4 \AA$ (b)

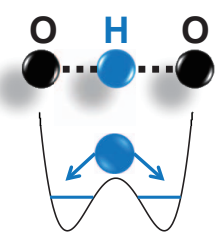

$R_{\mathrm{OO}} \sim 2.5 \AA$ (c)

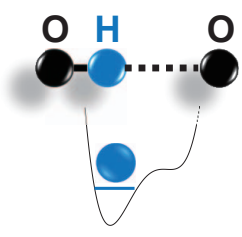

$R_{\mathrm{OO}}>2.5 \AA$
Figure 2. A schematic drawings of (a) single minimum, (b) symmetric double-minimum, and (c) asymmetric potential energy curve as a function of the distance between $\mathrm{O}$ and $\mathrm{H}$ atoms, where $\mathrm{H}$ atom moves linearly between the $\mathrm{O}$... O hydrogen bond ${ }^{26,27}$. 


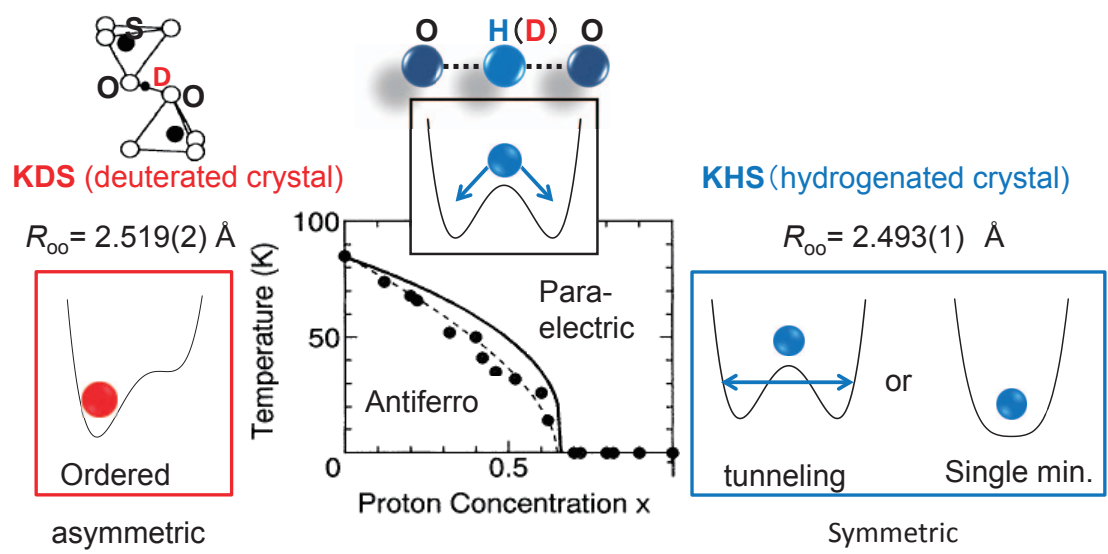

Figure 3. Proton concentration dependence of transition temperatures in $\mathrm{K}_{3} \mathrm{D}_{1-\mathrm{x}} \mathrm{H}_{\mathrm{x}}\left(\mathrm{SO}_{4}\right)_{2}{ }^{30}$, composed of zero dimensional hydrogen bond unit. The hydrogenated crystal $(x=1, \mathrm{KHS})$ is paraelectric down to low temperatures with symmetric potential energy curve, whereas the deuterated crystal $(x=0, \mathrm{KDS})$ shows antiferroelectric order at $85 \mathrm{~K}$ with asymmetric one.

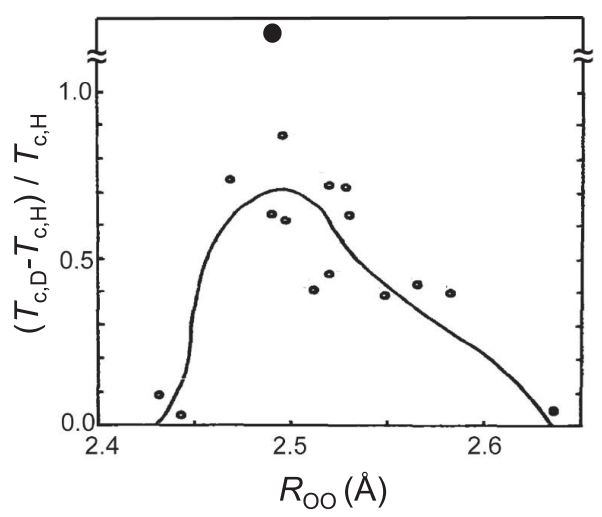

Figure 4. Hydrogen bond distance $\left(R_{\mathrm{OO}}\right)$ dependence of relative deuterium isotope shift, $\left(T_{\mathrm{c}, \mathrm{D}}-T_{\mathrm{c}, \mathrm{H}}\right) / T_{\mathrm{c}, \mathrm{H}}$. The black circles and black solid circle denote the experimental isotope shift for various antiferro/ferroelectric crystals ${ }^{31}$ and $\mathrm{K}_{3} \mathrm{H}\left(\mathrm{SO}_{4}\right)_{2}{ }^{30}$, respectively. The molecular crystals $\kappa$ - $\mathrm{Y}_{3}(\text { Cat-EDT-TTF })_{2}[\mathrm{Y}=\mathrm{H}, \mathrm{D}]$ with $R_{\mathrm{OO}} \sim 2.5 \AA$ in this article afford the largest isotope shift.

\section{られ，それ以上では反強誘電相の長距離秩序が抑えられて いる ${ }^{30}$ 。}

Figure 4 では, 高温相で対称型水素結合を持つ 16 個の 反 /強誘電体について, $R_{\mathrm{OO}}$ の距離と, 同位体効果による 転移温度シフト率 $\left[=\left(T_{\mathrm{c}, \mathrm{D}}-T_{\mathrm{c}, \mathrm{H}}\right) / T_{\mathrm{c}, \mathrm{H}}\right]$ をプロットしている ${ }^{31}$ 。 強い水素結合 $\mathrm{O} . . \mathrm{H}(\mathrm{D}) . . \mathrm{O}$ の中でも $R_{\mathrm{OO}}$ の距離が〜 $2.5 \AA$ の とき, 最大の幾何学的効果と水素原子の高いゼロ点振動工 ネルギーによる量子的効果で, 同位体による転移温度シフ 卜率は最高值となる。この振る舞いは, 反 /強誘電体や $\mathrm{K}_{3} \mathrm{H}\left(\mathrm{SO}_{4}\right)_{2}$ ばかりでなく, 本稿の主題であり, 筆者らが開 発した純有機結晶 $\kappa-\mathrm{H}_{3}(\mathrm{Cat}-\mathrm{EDT}-\mathrm{TTF})_{2}$ でも観測されてい る $16,18,19$ 。重水素効果による転移温度の上昇は, 前者が 85 $\mathrm{K}$ であるのに対して，筆者らの $\pi$ 電子一水素協奏系は 185 $\mathrm{K}$ と約倍で, 我々の知る限り最高の同位体効果が観測され ている。詳細については $3.2 .3 て ゙$ 述べる。

\section{3. $\pi$ 電子と水素の協奏機能物性 \\ $3.1 \pi$ 電子と水素が協奏する系の開発}

2 章では, 水素における機能物性として, 対称型ダブル ミニマムポテンシャルエネルギーを熱的にホッピングする 無秩序状態から，協奏的に重水素が秩序化する反強誘電相 転移について述べた。3 章では，この水素と $\pi$ 電子が協奏 する新たな静的・動的機能物性を開拓したので解説する。

生体系および化学反応において，水和および溶媒中にお けるエネルギー変換の重要な過程で, 電子と水素イオンで あるプロトンがカップルした反応を分子レベルで見ること が多い。生命は 30 億年前から光エネルギーを化学エネル ギーに変える反応過程で, 電子とプロトンの協奏効果を用 いている。例えば, 光合成の $\mathrm{Z}$ 機構では, チコライド膜内 の光化学系 (PSII) で水を分解し, $\mathrm{H}_{2} \mathrm{O}->\mathrm{O}_{2}+2 \mathrm{H}^{+}+2 \mathrm{e}-$, この電子が電子伝達系を移動する時のエネルギーを使って, プロトンを二重脂質膜内に取り込み, 膜内外のプロトン濃 度勾配を用いて，アデノシン二リン酸（ADP）からアデノ シン三リン酸（ATP）をまた, 光化学系 (PSI) で, ニコチ ン酸アミドアデニンジヌクレオチドリン酸の酸化体 $\left(\mathrm{NADP}^{+}\right)$から還元体（NADPH）を作る。特に前者の電子 伝達系におけるキノンプールでは, パラベンゾキノンとパ ラジヒドロキシベンゼン間で変化する際, 電子とプロトン の協奏反応が起きている。

この生体系のキノン一ヒドロキノン反応に倣い, 我々は プロトンが関わる酸一塩基系と $\pi$ 電子系を融合して, 新た に $\pi$ 電子と，プロトンおよび水素が協奏する機能物性開拓 を行った ${ }^{11}$ 。具体的には, Figure 5 に示すように, 水素部 位としてオルトジヒドロキシベンゼンのカテコール (Cat) を, $\pi$ 電子部位として, 伝導体として通常用いられるテト ラチアフルバレン（TTF）誘導体を縮環して融合したCatTTFを分子設計した。中性の Cat-EDT-TTFの分子軌道を Gaussian プログラム (U)B3LYP/6-31+G* with PCM(MeCN)を 用いて計算すると，最高占有分子軌道（HOMO）は主に 
(a)

TTF Catechol

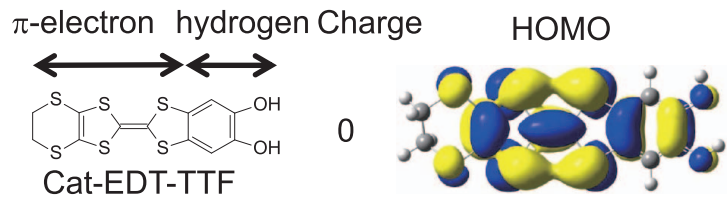

(b)

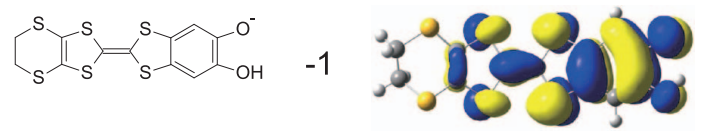

(c)

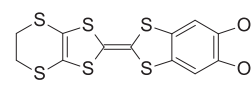

$-2$

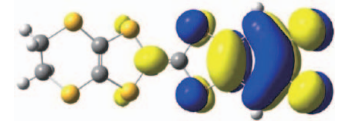

Figure 5. HOMO molecular orbitals of Cat-EDT-TTF-based molecules. By the removal of protons, HOMO orbitals shift from TTF to catechol side.

TTF 主体の軌道となり, 裾野がカテコールの酸素原子まで 広がる [Figure 5 (a)］。そして，プロトンを 1 個脱離させ てアニオンにすると, 分子軌道は混成によりカテコール側 にシフトして TTF とカテコールにおける電子密度分布がほ ぼ等しくなり [Figure 5 (b)], さらに2 個目のプロトンも 脱離するとジアニオンになり，カテコール主体の分子軌道 となる [Figure 5 (c) ]。このように, カテコール部位 (Cat-, 水素部分) と TTF 部位（TTF， $\pi$ 電子部分）が融合したCatTTF は, 分子レベルでプロトンの脱着と分子軌道の変化が 連動した系であることが分子軌道計算より示された。

実際，合成に係わった研究室の大学院生とスタッフの熱 心な取り組みで，保護基を 2 回変える 6 ステップの反応に より 新規 Cat-TTF 誘導体の合成に 1 年かけて成功した。合 成した一連の Cat-TTF 誘導体について酸化還元を調べたと ころ, Figure 5 の中性分子軌道計算で示されるとおり, TTF 部分の 2 電子酸化還元電位能を反映していることが明らか となった ${ }^{11}$ 。

そこで， $\pi$ 電子と，プロトンおよび水素が協奏する機能 性の発現を目指して, Cat-TTF が構成成分となる有機結晶 の作成を試みた。Figure 6 で示すように，有機溶媒に溶解 した例えば Cat-EDT-TTF ドナー分子を, 弱塩基 (2,2-ビピ リジン）で脱プロトンしながら，電解質であるへキサフル オロりん酸テトラブチルアンモニウム $\left(\mathrm{TBAPF}_{6}\right)$ の存在下, 電気化学的に定電流で酸化しながら結晶成長すると（電気 化学的成長法), 黑色の純有機結晶 $\kappa-\mathrm{H}_{3}(\mathrm{Cat}-\mathrm{EDT}-\mathrm{TTF})_{2}$ が 得られた ${ }^{12,13,16 。 2 ~}$ 章の誘電体の KHS (KDP) では, ジア ニオン $\left(\mathrm{SO}_{4}\right)^{2-}$ が Roo 〜 2.5 $\mathrm{A}$ の強い O..H..O 水素結合で連 結し，水素結合ユニットを形成していた。一方，この $\kappa-\mathrm{H}_{3}$ $(\text { Cat-EDT-TTF })_{2}$ では, 酸化した $\pi$ 電子系 TTF ドナー分子が 強い $R$ oo $2.5 \AA$ の O..H..O 水素結合で結ばれ, 水素結合ユ ニット作っている。Figure 6 (a) にこのユニットの化学構 造式が示されているが，+0.5 価に酸化された結晶学的にも 等価な 2 個の $\pi$ 電子系の Cat-EDT-TTF ${ }^{0.5+}$ が $(\mathrm{OHO})^{1-}$ で結 (a)
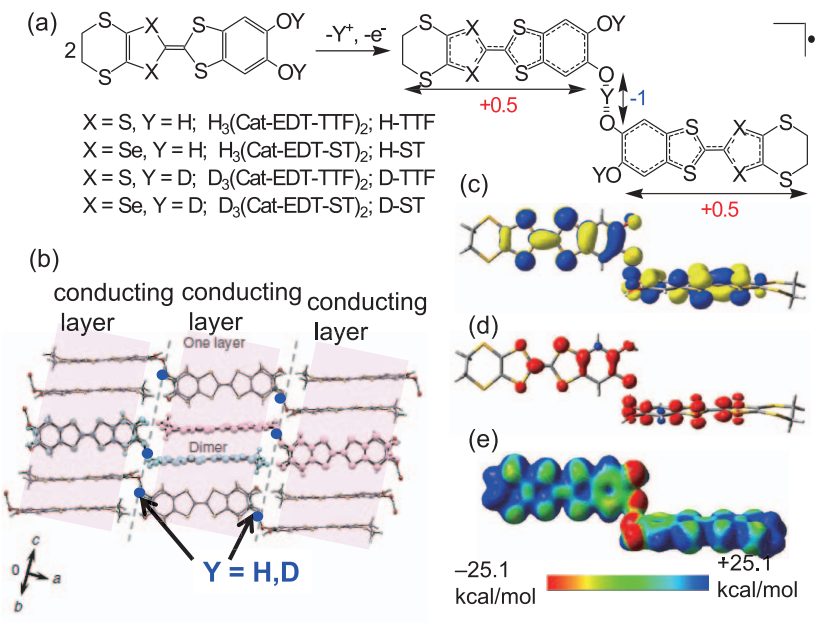

Figure 6. (a) Electrocrystallization and (b) crystal structures of $\kappa$-Y ${ }_{3}\left(\right.$ Cat-EDT-X' $_{2}\left[\mathrm{X}^{\prime}=\mathrm{TTF}, \mathrm{ST}, \mathrm{Y}=\mathrm{H}, \mathrm{D}\right]$, (c) HOMO distribution, (d) spin distribution, and (e) electrostatic potential surface of $\mathrm{H}_{3}$ (CatEDT-TTF $)_{2}$.

ばれ，中性のラジカルユニットを形成している。このユ ニットの（c）HOMO 軌道, また（d）のスピンの分布は TTF 部分ばかりでなく, 両者の連結部であるカテコール部 分にまで広がっていて, 水素結合ユニット軌道となってい る。また, (e) 静電ポテンシャルをみると, $\pi$ 電子系の TTF 部分の電荷分布は正であるのに対して, 水素結合 $(\mathrm{OHO})^{1-}$ の部分は負であることが示されている。

この水素結合ユニットが, 溶液における電気化学的結晶 成長法で集積した時の結晶構造が, Figure 6（b）に表され ている。例えば，水色とピンク色の 2 個の水素結合ユニッ 卜は， $\pi$ 電子系 TTF二量体を形成し，その二量体同士は, 井桁型のように配列して， $\kappa$ 型と名付けられた分子配列を しながら集積し, 2 次元伝導層を作っている。通常の有機 伝導体では, この 2 次元伝導層間に電荷供給層としてのア ニオンあるいはアクセプターがある。しかし，この系にお いてそれらは存在せず, 強い $\mathrm{OHO}$ 水素結合 $(R \mathrm{oo} \sim 2.5 \AA)$ のみで連結された大変珍しい系となっている。この $\pi$ 電 子一水素系は, 開殼の中性ラジカルから構成されているが, 「純有機の単成分伝導体として金属性あるいは超伝導性を示 すのか？」，伝導層は三角格子を形成しているが「層内のフ ラストレートした磁性と層間を連結する水素結合における 水素の量子性はカップルして, 低温までスピンは摇らぐの か？」，伝導層間の水素結合水素を重水素に置き換えたとき， $\lceil$ 伝導層内の $\pi$ 電子は相関して変化するのか? 」という問 題意識をもって研究を進めたところ, 新たに $\pi$ 電子と水素 が協奏する機能物性を見出したので次に述べる（Figure 7）。

\section{$3.2 \pi$ 電子と水素の協奏による機能物性}

3.2 .1 自己ドープによる純有機単成分金属 $12,13,15,16$

通常，単一成分の有機物質は半導体または絶縁体であり， 例えばポリアセチレンは, 室温抵抗率が $10^{4} \mathrm{ohm} \mathrm{cm}$, バン ドギャップが $0.56 \mathrm{eV}$ の半導体で，ポリ塩化ビニルは, $10^{16}$ 


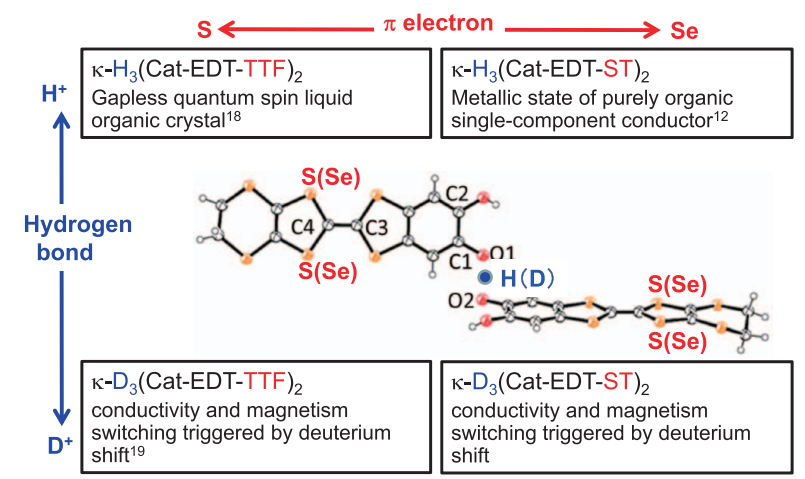

Figure 7. Functional properties of the electron-hydrogen concerted crystals by controlling $\pi$-electrons and hydrogen in hydrogen bonds. The quantum spin liquid state in organic crystal, $\kappa-\mathrm{H}_{3}(\text { Cat-EDT-TTF })_{2}{ }^{18}$, metallic state of purely organic single-component conductor, $\kappa-\mathrm{H}_{3}(\mathrm{Cat}-$ EDT-ST $)_{2}{ }^{12}$, and the conductivity and magnetism switching triggered by deuterium shift, $\kappa$ - $\mathrm{D}_{3}(\text { Cat-EDT-TTF })_{2}{ }^{19}$ and $\kappa$ - $\mathrm{D}_{3}(\text { Cat-EDT-ST })_{2}$, respectively.

ohm cm より大きく, リード線の被覆絶縁材料として利用 されている。「単成分純有機物は電気を流さない」という常 識を覆す材料を開発することは, 昔から化学者の夢であり, 基礎的および応用的な観点で大変重要な課題である。

Figure 8 に, 純有機単成分伝導体における物質開発の歴 史を示した ${ }^{13,15,32-36}$ 。通常, 有機物は閉殼なので半導体, あるいは絶縁体であることを述べた。しかし，空気中安定 であり, 平面性の高い中性の開殼分子, つまり不対電子を 持つ中性ラジカル分子が開発できれば，高い伝導性を有す る有機物ができると考えられてきた。Figure 8 の下部に示 す中性ラジカル $(\mathrm{a})^{32},(\mathrm{~b})^{33}, \quad(\mathrm{c})^{34}$ は, $\pi$ ラジカル電子の 共役性が高く, 平面分子全体に広がっている。固体中, 中 性ラジカル分子は積み重なり, ラジカルが分子間を移動し て, 積層方向に伝導性を有する。1 分子に 1 ラジカル電子 があるため, ラジカル電子間のクーロン相互作用が比較的 強く, 常圧室温で, 伝導度は $10^{-2} \mathrm{Scm}^{-1}$ が上限である。 $(d)^{35},(e)^{36}$ は両性イオン型ラジカルであり, 不対電子を持 ち, かつ分子内で電子分極性が高いため, クーロン相互作 用は多少緩和され, 常圧室温での伝導度は $10^{-1} \mathrm{Scm}^{-1}$ と, 一桁高い伝導度を有する。中性ラジカル（c）に7.3 GPa と いう高圧を印加すると $1 \mathrm{Scm}^{-1}$ を示し, 室温付近で金属的 挙動を示すという報告があるが, これ以上の展開はなかな か難しい状況であった。

その中で, 我々が開発した $\pi$ 電子一水素協奏系は, Figure 6（a）で示すように，分子から水素イオンであるプロトン を引き抜き, 電荷を補償するためにホールが注入されて Cat-EDT-TXF ${ }^{0.5+・}(\mathrm{X}=\mathrm{S}, \mathrm{Se})$ となり, 自己ドープによる伝 導キャリアの生成が実現した。そして, これらの自己ドー プ型の分子が集積して伝導パスを形成し, Figure 8 (f1), （f2）のように，3/4充填バンドを形成する単成分純有機伝 導体である $\kappa-\mathrm{H}_{3}(\mathrm{Cat}-\mathrm{EDT}-\mathrm{TTF})_{2}$ と $\kappa-\mathrm{H}_{3}(\mathrm{Cat}-\mathrm{EDT}-\mathrm{ST})_{2}$ が得 られた。常圧室温伝導度は, (f1) の硫黄体で, $3.5 \mathrm{Scm}^{-1}$, 結晶学的に同型のセレン体（f2）で, $19 \mathrm{Scm}^{-1}$ と Figure 8
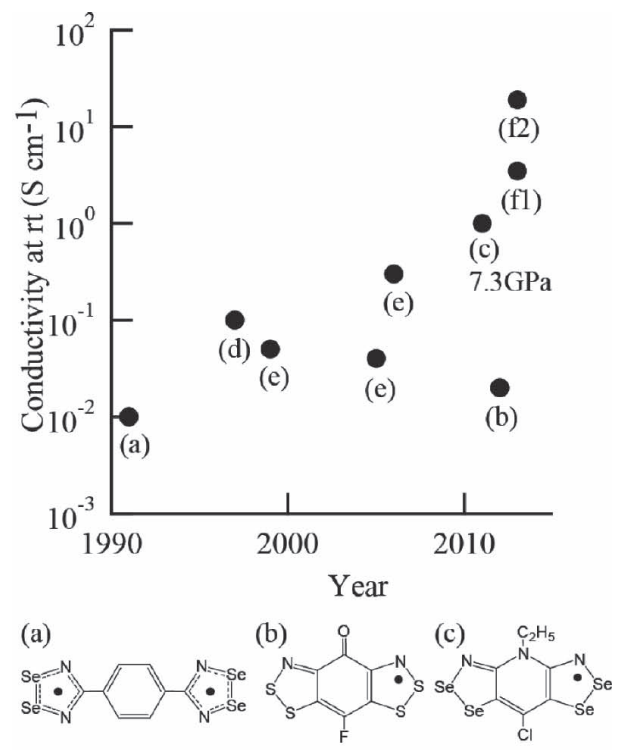

(d)

(e)

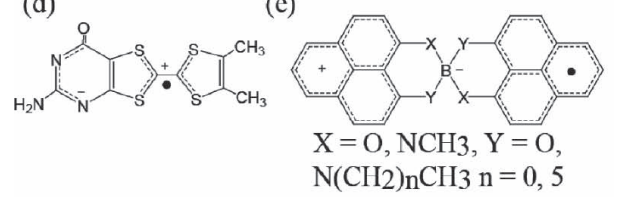

$[\mathrm{fl} ; \mathrm{X}=\mathrm{S}$;

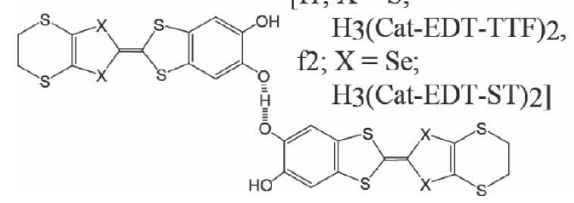

Figure 8. Electrical conductivities at room temperature vs. year for purely organic single component conductors ${ }^{13,15,32-36}$.

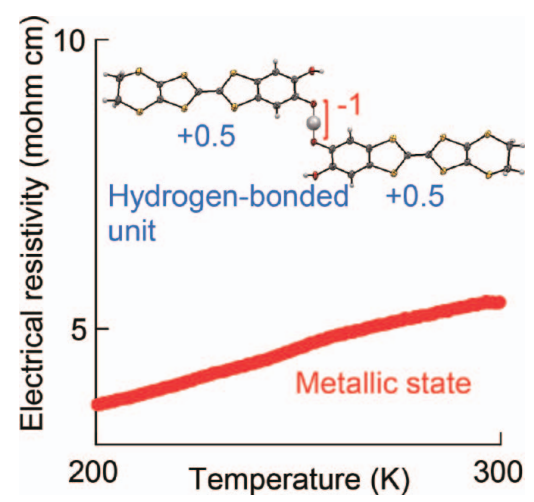

Figure 9. Metallic state of purely organic single component conductors under pressure for $\kappa-\mathrm{H}_{3}(\mathrm{Cat}-\mathrm{EDT}-\mathrm{ST})_{2}(1.3 \mathrm{GPa})^{12,16}$.

に示すように, 純有機の単成分伝導体では, これまでで最 高の值を持つ。本系は, 従来の中性ラジカルより, 2 次元 的でかつ強い分子間相互作用を有し, 特に硫黄体に比べて, セレン体ではバンド幅が 1.7 倍であると計算されている。そ ればかりでなく，従来の開殼系単成分伝導体では 1 分子に 1 電子であったのに対して, 今回は 2 分子で 1 電子, つま り 1 分子で平均 0.5 電子であるため, 電子間のクーロン斥 力が小さくなり，伝導度が向上していると考えられる。ま た, Figure 9 に示すように, セレン体 $\kappa-\mathrm{H}_{3}(\text { Cat-EDT-ST })_{2}$ に 圧力を印可したところ，1.3 GPa とこれまでで一番小さい圧 
力において，室温伝導度は $130 \mathrm{Scm}^{-1}$ が得られ，室温付近 で金属状態を示した。

このように， $\pi$ 電子一水素協奏系の分子を用い, 自己 ドープにより, 純有機単成分伝導体でも圧力下で金属状態 を示す伝導体ができることを本章では紹介した。水素結合 の中心にある水素は低温まで偏ることなく，水素結合ユ ニットの中心を保っているので, 今後さらに $\pi$ 電子軌道を 広げるよう分子設計すると, 常圧で金属状態, ひいては超 伝導状態を示す純有機単成分伝導体を開発することも可能 であると考えている。

\section{2 .2 量子スピン液体 ${ }^{16,18}$}

温度を下げると, 水は運動エネルギーを失い, 水（固体） に相転移する。同様に，磁性体中の電子スピンも，通常， 低温では整列し, 基底状態は強磁性, 反強磁性, あるいは 非磁性相とスピンの固体として長距離秩序を示す。しかし, Figure 10 (a) のように, 正三角格子に $S=1 / 2$ のスピンを 反強磁性的に並べようとすると, ある場所はスピンの向き が決められず，「三すくみ」や「三つ巴」というフラスト レーション状態となる。このように, フラストレートした 状態を持つために基底状態が長距離秩序を持たない状態を 「スピン液体状態」と呼び, この量子スピン液体物質の探索 が長年行われてきた。

このスピン液体に対する理論的アプローチとして有名な のが, 1973 年アンダーソン博士（Anderson, P. W., ノーベ ル物理学賞受賞者）が示した「RVB (resonating valence bond)」状態 [Figure 10 (b) $]^{37,38}$ である。三角格子上で, 2 つの $S=1 / 2$ スピンが強く結合してスピン一重項状態を形成 し, 量子的な効果に加え, 三角格子の持つフラストレー ションの効果のため, 常にスピン一重項ペアが入れ替わっ ているような状態である。これは, 銅酸化物高温超伝導体 (a)

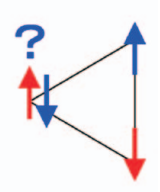

(b)

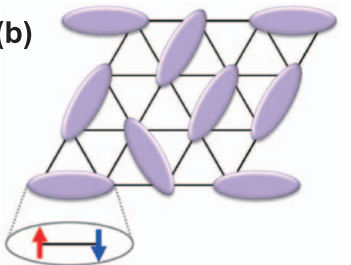

(c)

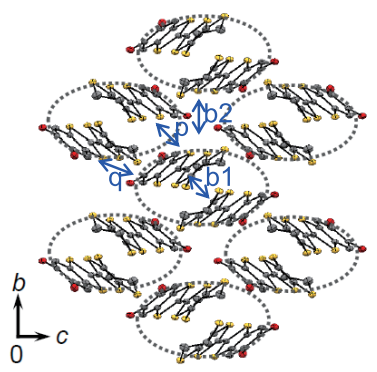

(d)

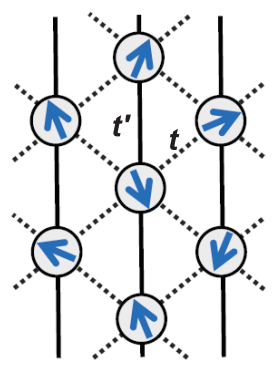

Figure 10. (a) $S=1 / 2$ spin frustration in triangle lattice, (b) RVB (resonating valence bond) $\operatorname{state}^{32,33}$, (c) $\kappa$-type donor arrangement, (d) $S=1 / 2$ triangle lattice of $\kappa-\mathrm{H}_{3}(\text { Cat-EDT-TTF })_{2}$. In (c), transfer integrals are as follows; $\mathrm{b} 1=230, \mathrm{~b} 2=85, \mathrm{p}=46$, and $\mathrm{q}=12 \mathrm{meV}^{12}$.
に関しても提唱された理論であるが，スピン液体を表現す る有力な候補である。

このように, 理論からの提案により長年の物質探索が行 われ, 2003 年以後に, 量子スピン液体状態を示す $\kappa$-(BEDT$\mathrm{TTF})_{2} \mathrm{Cu}_{2}(\mathrm{CN})_{3}{ }^{39,41}$ や $\mathrm{EtMe}_{3} \mathrm{Sb}\left[\mathrm{Pd}(\mathrm{dmit})_{2}\right]_{2}{ }^{40,41}$ という $2 つ の$ 有機三角格子系結晶が見出されたが，両者のスピン液体と しての振る舞いは全く異なるため, スピン状態の本質を理 解するには程遠く, さらなる量子スピン液体状態を示す物 質の発見が渇望されていた。そして，2014 年に我々が開発 した $\pi$ 電子一水素協奏系 $\kappa-\mathrm{H}_{3}(\mathrm{Cat}-\mathrm{EDT}-\mathrm{TTF})_{2}$ も量子スピン 液体候補であることを突き止めた。

Figure 6 (b) のように, 本有機結晶の 2 次元伝導層は bc 面で広がっており，この 2 次元層間は水素結合で連結され ている。この 2 次元層における分子配列は Figure 10 (c) の ように，水素結合ユニット $\mathrm{H}_{3}(\mathrm{Cat}-\mathrm{EDT}-\mathrm{TTF})_{2}$ が， $\pi$ 電子間 の相互作用により点線で囲まれた二量体を形成し, さらに この二量体が二次元三角格子を形成している。Figure 10 （d）にあるとおり，三角格子点に $S=1 / 2$ のスピンが局在 している。他のスピン液体候補の三角格子 $t^{\prime} / t$ (三角格子の 歪の程度の目安）は拡張ヒュッケル法（あるいは第一原理 計算) で $1.06(0.80-0.83)\left[\kappa-(\mathrm{BEDT}-\mathrm{TTF})_{2} \mathrm{Cu}_{2}(\mathrm{CN})_{3}\right]^{39,41}$ と $0.92(0.79-0.82) \quad\left[\mathrm{EtMe}_{3} \mathrm{Sb}\left[\mathrm{Pd}(\mathrm{dmit})_{2}\right]_{2}{ }^{40,41}\right.$ と求められてい るのに対して, 本結晶は $1.48(1.25)^{12,42}$ と異方的である。

そこで，本結晶 $\kappa-\mathrm{H}_{3}(\mathrm{Cat}-\mathrm{EDT}-\mathrm{TTF})_{2}$ について静磁化率の 温度依存性を調べたところ, Figure 11 の黒線のように温度 低下とともに増加し, およそ $20 \mathrm{~K} て ゙$ 幅広い極大を持ち, $J=$ -80〜-100 K 三角格子ハイゼンベルグ型モデルで最適化さ れることが明らかとなった。さらに低温における長距離秩 序の有無について，カンチレバーを用いたトルク測定を 行った。一般に, 常磁性状態では, トルク $\tau$ は, $\tau(\theta, H)=$ $A H^{2} \cdot \sin 2\left(\theta+\theta_{0}\right)$, ただし, $\theta$ は印加磁場の角度, $H$ は磁場, $A$ は定数, $A H^{2}$ は振幅で最適化される。また，長距離秩序に より内部磁場が発生すると, 角度依存性は 2 倍周期の正弦 曲線からピーク構造に変化する。0.4 Kにおける測定の結 果, トルク $\tau$ は 2 倍の正弦曲線に従い, 振幅も $20 \mathrm{~T}$ まで磁 場の 2 乗に比例すること，また同様の振る舞いが $50 \mathrm{mK}$ ま で観測されることが明らかとなった。このように，三角格 子のフラストレーション効果により, 約 $J / 1000$ の極低温ま で長距離秩序を持たない常磁性状態であることから, 量子 スピン液体の候補となった。

さらに, 約 $3 \mathrm{~K}$ から $50 \mathrm{mK}$ という極低温領域まで静磁化 率とトルク測定（Figure 11 の赤四角印）から磁化率を見積 もったところ, 温度依存せず一定となっており, 本結晶が ギャップレスの量子スピン液体状態であることを示唆して いる。

これまでに発見された量子スピン液体物質である $(\mathrm{BEDT}-\mathrm{TTF})_{2} \mathrm{Cu}_{2}(\mathrm{CN})_{3}$ や $\mathrm{EtMe}_{3} \mathrm{Sb}\left[\mathrm{Pd}(\mathrm{dmit})_{2}\right]_{2}$ では, 三角格 子状に位置する二量体内のスピンの局在ばかりでなく, 二 


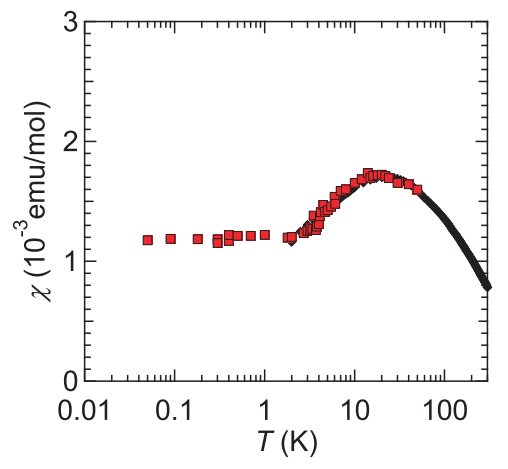

Figure 11. Temperature dependence of magnetic susceptibility of $\kappa$ - $\mathrm{H}_{3}(\text { Cat-EDT-TTF })_{2}{ }^{18}$. The solid black and red squares denote the results of static magnetic susceptibility and magnetic torque measurements, respectively.

量体内の電荷の自由度が量子スピン液体状態を安定化する のに重要であるという提案がなされている。前者の $\kappa$ $(\mathrm{BEDT}-\mathrm{TTF})_{2} \mathrm{Cu}_{2}(\mathrm{CN})_{3}$ では，観測された $60 \mathrm{~K}$ 以下でのリラ クサー的な誘電応答は, 二量体内の電荷の摇らぎを起源と しているとも提案されており, 後者 $\mathrm{EtMe}_{3} \mathrm{Sb}\left[\mathrm{Pd}(\mathrm{dmit})_{2}\right]_{2}$ で は, $t^{\prime} / t$ を横軸とした相図で, 量子スピン液体相は, 反強磁 性相と電荷秩序相に挟まれていると報告されている。この ように, 量子スピン液体相の近傍に電荷秩序相が存在して いることが理論的にも実験的にも提案されている。

上記の $\kappa-(\mathrm{BEDT}-\mathrm{TTF})_{2} \mathrm{Cu}_{2}(\mathrm{CN})_{3}$ や $\mathrm{EtMe}_{3} \mathrm{Sb}\left[\mathrm{Pd}(\mathrm{dmit})_{2}\right]_{2}$ と も比較して Cat-EDT-TTF 分子の二量体が作る三角格子は, $t^{\prime} / t=1.48$ と正三角格子（ $\left(t^{\prime} / t=1 ）\right.$ から大きく歪んでおり, それにもかかわらず，量子スピン液体状態を示唆している ことは大変興味深い。本物質は, 上記 2 物質とは異なり, 二次元三角格子の各層が互いに水素で繋がれているところ に特徵がある [Figure 6 (b)]。この水素が低温で, 有機分 子間の中心位置から冕れて量子的に摇らいでいる時, 水素 結合で繋がれた有機分子間で電荷も協奏的に摇らぐ。この 電荷の摇らぎが, スピンの長距離秩序を不安定化させ，つ まり量子スピン液体状態を安定化しているかもしれないと 考え，実験をさらに進めている。

3.2.3 重水素移動と $\pi$ 電子移動の協奏による伝導性と磁性 のスイッチング 16,19

2 章では, 水素結合型反強誘電体に扔いて, OHO および $\mathrm{ODO}$ の酸素原子間距離 $\left(R_{\mathrm{OO}}\right)$ がわずか $0.03 \AA$ 違うと, 85 $\mathrm{K}$ にも及ぶ大きな同位体効果があることを述べた。本章で は， $\pi$ 電子一水素協奏系において，その約 2 倍の $185 \mathrm{~K}$ に も及ぶ巨大な同位体効果があり, その起源が, 重水素移動 と協奏した $\pi$ 電子の移動により伝導性と磁性の切替わりと いう大変珍しい現象であることが明らかになったので紹介 する。

Figure 6（a）において，Yをすべて水素から重水素に置 換するため, 水素体 $\mathrm{H}_{2}$ (Cat-EDT-TTF) を原料として重メ夕 ノール溶媒を含む混合溶媒を用いて, 弱アルカリおよび電

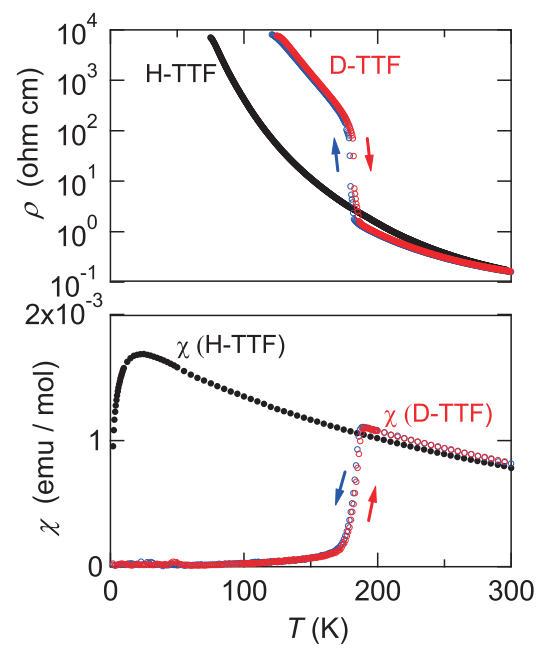

Figure 12. Temperature dependence of (a) electrical resistivity and (b) magnetic susceptibility for $\kappa-\mathrm{H}_{3}(\mathrm{Cat}-\mathrm{EDT}-\mathrm{TTF})_{2}[\mathrm{H}-\mathrm{TTF}]^{16,18}$ and $\kappa-\mathrm{D}_{3}(\text { Cat-EDT-TTF })_{2}[\mathrm{D}-\mathrm{TTF}]^{16,19}$.

解質の共存下, 電気化学的な結晶成長を行い重水素体 $\kappa$ $\mathrm{D}_{3}(\text { Cat-EDT-TTF })_{2}$ を得た。この重水素体では, Figure 6 (b) に示すように, 室温において伝導層間は O..D..O という強 い水素結合 $R_{\mathrm{OO}}=2.501(2) \AA$ で連結されている。空気中に 晒すと, 1 年ほどで水素体に一部置換されるが, 重溶媒中 で保管すればほぼ100\%の重水素化率を保つことができる。 前章 3.2.2 にように, 水素体 $\kappa-\mathrm{H}_{3}(\mathrm{Cat}-\mathrm{EDT}-\mathrm{TTF})_{2}$ は, 極 低温まで長距離秩序がみられない量子スピン液体状態であ るため, Figure 12 に示すように, 電気伝導率の温度依存性 は室温で $\sigma=4 \mathrm{~S} \mathrm{~cm}^{-1}$, 活性化エネルギー $E \mathrm{a}=0.11 \mathrm{eV} の$ 半導体で, 磁化率も, $J=-80 \sim-100 \mathrm{~K}$ の三角格子の八イ ゼンベルグ型で低温まで最適化されることを述べた。それ に対して, 重水素体は, 室温の伝導率はほぼ変わらず $\sigma=$ $6 \mathrm{~S} \mathrm{~cm}^{-1}$ で, 室温から $185 \mathrm{~K}$ までは, 活性化エネルギーが 水素体よりやや小さい $E \mathrm{a}=0.08 \mathrm{eV}$ の半導体であるが, 185 $\mathrm{K}$ で抵抗率のスイッチングが起こり, 温度低下とともに抵 抗率も急上昇する。磁化率も，185 K までは水素体とほぼ 同じ振る舞いを示すが, 抵抗率の切り替えと同じ温度で, 突如非磁性へスイッチングを起こすことが明らかとなった。

そこで, このスイッチングの起源を結晶構造から解き明 かすために, 高エネルギー研究所の放射光施設で，スイッ チング温度前後の詳細な構造決定を行った。水素結合工 ニットの中心に位置する水素結合 O..H..O, O..D..O の部分 であるが, Figure 13 に示すように, $270 \mathrm{~K}$ では水素も重水 素も, 酸素原子間中心の 2 回軸上にあり, $R_{\mathrm{OO}}$ 距離は水素 体で 2.486(5) ̊, 重水素体で 2.501(2) ̊ と後者の方が 0.015 凡とほんの少しだけ長い。これらの結晶を冷却し，50 K で 測定したところ, 水素体の水素の電子密度は中心に留まり, $R_{\mathrm{OO}}$ 距離は 2.453(5) $\AA$ と室温より $0.032 \AA$ 短くなった。一 方, 重水素体は $185 \mathrm{~K}$ 以下で空間群が $\mathrm{C} 2 / \mathrm{c}$ から $\mathrm{P}-1$ に構 造変化し, $R_{\mathrm{OO}}$ 距離は転移前後で $2.501 \AA$ と変わらないも のの, 伝導性抢よび磁性のスイッチングとともに重水素の 
位置も中心から偏り，O-D..O と非対称化することが放射 光 $\mathrm{X}$ 線による電子密度分布で明らかとなった。

Figure 14 のように, 水素ユニットの中心で, 重水素が中 心から〜0.25 偏ると, 水素結合が $\left[\mathrm{O}^{-0.5} . . \mathrm{D} . . \mathrm{O}^{-0.5}\right]$ から $\left[\mathrm{O}^{-0.06}-\mathrm{D} . . \mathrm{O}^{-0.94}\right]$ へと変化する。それに伴い $\pi$ 電子系も両 側部分の中性を確保するため, -0.44 価の $\pi$ 電子が移動し て, 水素結合ユニットの $\pi$ 電子の価数は, $(+0.5,+0.5)$ から $(+0.06,+0.94)$ と非対称化する。つまり, 水素結合ユニット 全体の電荷に変化はないが, 重水素移動, およびそれと協 奏した $\pi$ 電子移動により，中心の水素結合の非対称化，お よびそれと協奏した $\pi$ 電子状態の変化が起きた。

水素結合ユニットの $\pi$ 電子状態の変化は, 集積体である 有機結晶の電子状態とも連動している。Figure 14 下部に示

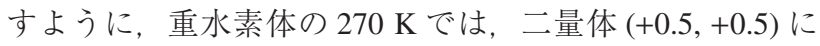

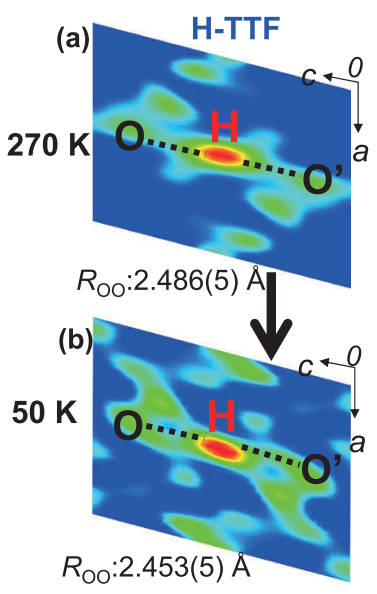

Symmetric

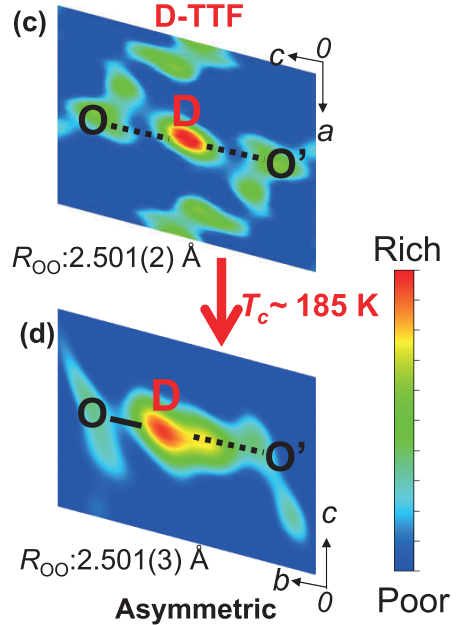

Asymmetric 0 Poor
Figure 13. Electron density map at (a) $270 \mathrm{~K}$, (b) $50 \mathrm{~K}$ for $\kappa-\mathrm{H}_{3}(\mathrm{Cat}-$ EDT-TTF $)_{2}[\mathrm{H}-\mathrm{TTF}]$ and (c) $270 \mathrm{~K}$, (d) $50 \mathrm{~K}$ for $\kappa$-D D $_{3}$ (Cat-EDT-TTF $)_{2}$ [D-TTF] by synchrotron X-ray at KEK PF BL- $8 \mathrm{~A}^{19}$.
$S=1 / 2$ のスピンが局在する「ダイマーモット絶縁体状態」 である。この結晶が冷却されると $185 \mathrm{~K}$ で重水素移動を契 機とする $\pi$ 電子系の電荷不均化が起こり，二量体 $(+0.5$, $+0.5)$ は, 2 種類の二量体として $(\sim+1, \sim+1)$ と $(\sim 0, \sim 0)$

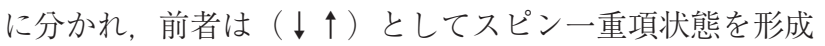
する。このように，水素を重水素に置換することにより， 室温では同じ電子状態であるにもかかわらず, 低温では重 水素と $\pi$ 電子が協奏し, 全く異なる基底電子状態を与える のは大変興味深い。

最後に, 水素を重水素に置換した時に, なぜ電子状態が 大きく変化したかをポテンシャルエネルギーカーブの計算 に基づいて考察してみる。Figure 15 は, 水素体と重水素体 について，室温および $50 \mathrm{~K}$ の結晶構造より水素結合ユニッ 卜を切り出し，水素および重水素を酸素原子 $\mathrm{O} 1$ と $\mathrm{O} 2$ 間で 移動させた時のポテンシャルエネルギーカーブ変化を DFT 計算で描いている。ここでは, ゼロ点振動など量子的な効 果は含まれていない。室温における水素体と重水素体は, $R_{\mathrm{OO}}$ 距離が各々 2.486(5) $\AA, 2.501(2) \AA$ と $0.015 \AA$ 長くなっ たため, ダブルミニマムポテンシャルエネルギーの障壁エ ネルギーも 0.09 から $0.14 \mathrm{eV}$ に上昇している。水素体の温 度を低下させると, $R_{\mathrm{OO}}$ 距離が $0.033 \AA$ 短くなるため, 障 壁エネルギーも 0.09 から $0.07 \mathrm{eV}$ に減少している。さらに, 重水素体の温度変化についてであるが, 驚くべきことに, $R_{\mathrm{OO}}$ 距離は $270 \mathrm{~K}$ と $50 \mathrm{~K}$ で $2.501 \AA$ と変化しないにもかか わらず，室温では対称的，低温では非対称的なポテンシャ ルエネルギーカーブを与えている。これは, O..D..Oの水素 結合ばかりでなく $\pi$ 電子系との協奏によってポテンシャ ルエネルギーの非対称化が誘発されたと考えられる。

Figure 16 でまとめたように, $\pi$ 電子一水素協奏系有機結 晶 $\kappa$ - $\mathrm{X}_{3}(\mathrm{Cat}-\mathrm{EDT}-\mathrm{TTF})_{2}[\mathrm{X}=\mathrm{H}, \mathrm{D}]$ は, 室温で両者ともダイ
$270 \mathrm{~K}$ symmetric unit

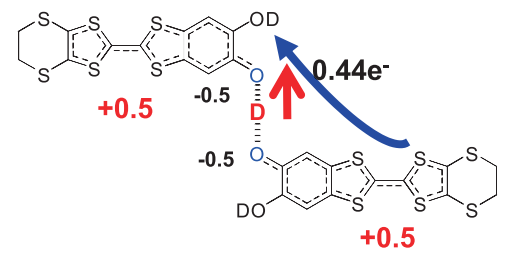

$50 \mathrm{~K}$ asymmetric unit

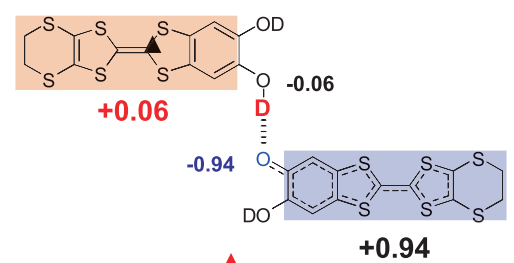

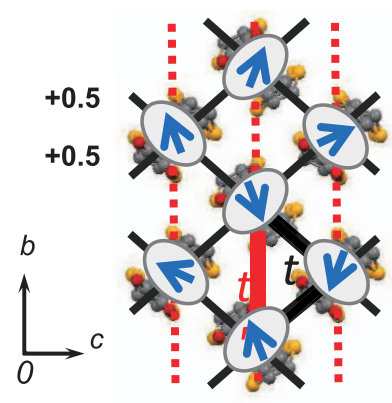

dimer-Mott; paramagnetic state

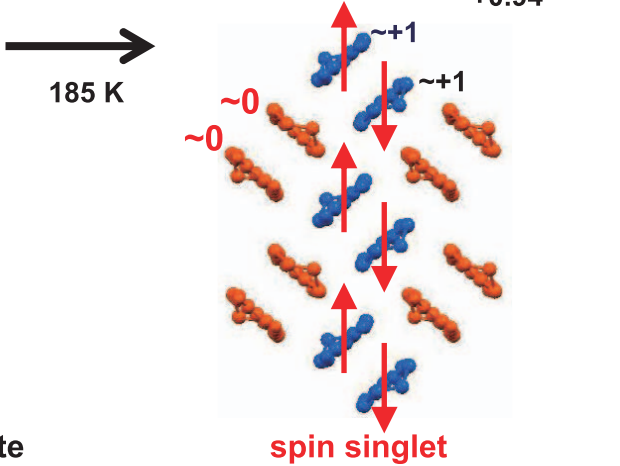

spin singlet

Figure 14. Symmetric hydrogen-bond units and dimer-Mott paramagnetic state at $270 \mathrm{~K}$, and asymmetric hydrogen-bond unit and spin singlet state at $50 \mathrm{~K}$ for $\kappa$ - $\mathrm{D}_{3}$ (Cat-EDT-TTF) $[\mathrm{D}-\mathrm{TTF}]^{16,19}$. 

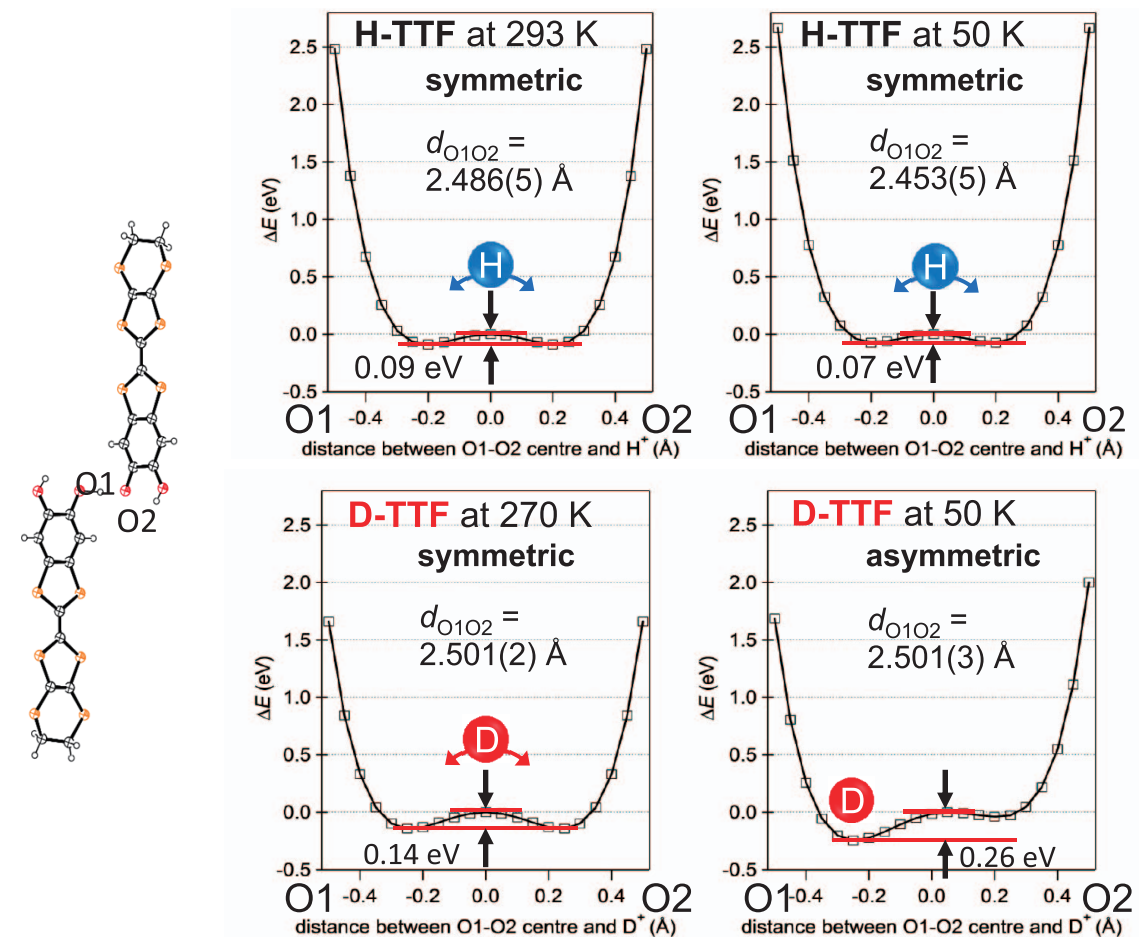

Figure 15. Calculated potential curve as a function of the distance between the $\mathrm{O} 1 \ldots \mathrm{O} 2$ center position and the hydrogen at room temperature and $50 \mathrm{~K}$ for $\kappa-\mathrm{X}_{3}(\text { Cat-EDT-TTF })_{2}[\mathrm{X}=\mathrm{H} \text { and D }]^{19}$.

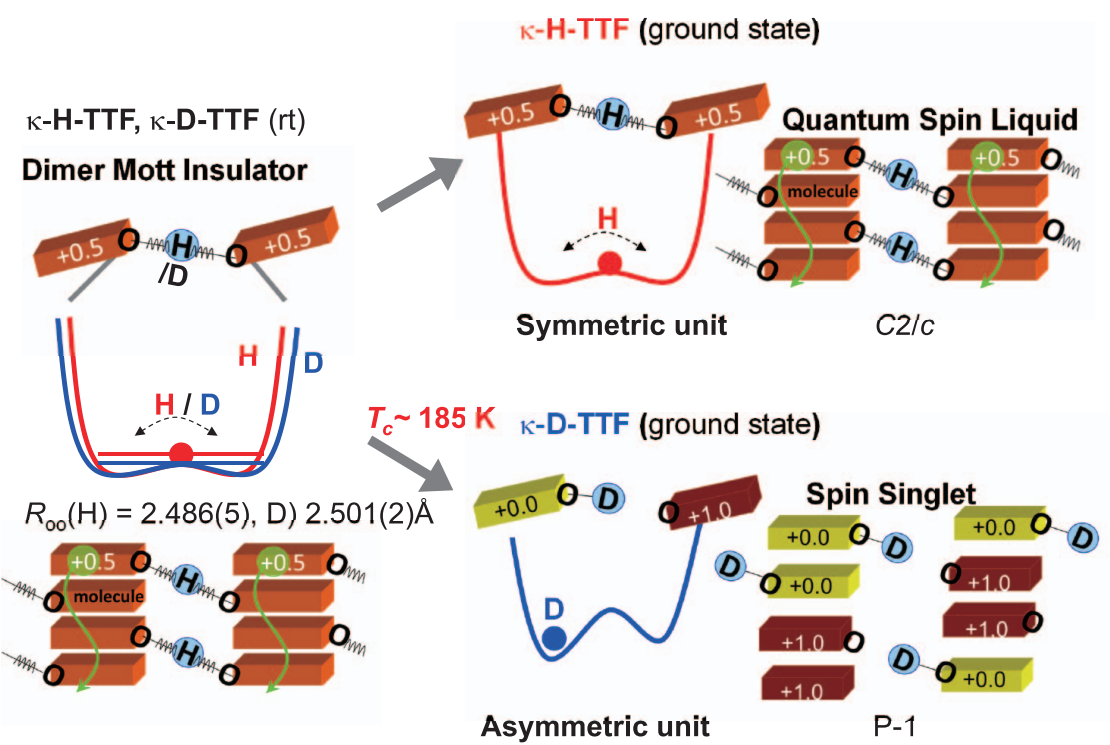

Figure 16. The electronic states at room temperature (rt) and ground states of $\pi$-electron-hydrogen concerted purely organic crystals, $\kappa$ - $\mathrm{X}_{3}(\text { Cat-EDT-TTF })_{2}[\mathrm{X}=\mathrm{H} \text { and } \mathrm{D}]^{16}$.

マーモット状態で, 水素および重水素は水素結合ユニット の中央に位置し， $\pi$ 電子系も対称的である。温度が低下す

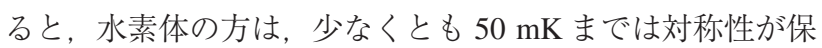
たれ，長距離秩序はなく，水素の量子効果が効くのか, 歪 んだ三角格子にもかかわらず量子スピン液体状態が実現し

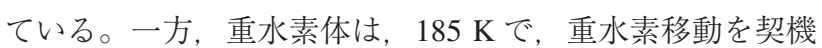
として水素結合およびそれに協奏した $\pi$ 電子系の非対称化 が起こる。このように動的な重水素に協奏した伝導性およ び磁性のスイッチングは大変珍しく, またその重水素効果 も $185 \mathrm{~K}$ と我々の知る限り最高の值となっている。このス
イッチングは, 水素結合の距離だけでなく, $\pi$ 電子の電子 状態と深く関係しているので, $\pi$ 電子の要請も含めた $\pi$ 電 子一水素の協奏現象が重水素効果を決めていると考えられ る。

\section{4. 今後の課題と展望}

本稿では, 純有機結晶において, $\pi$ 電子と水素の協奏に よる新機能性として，（1）水素イオンであるプロトンの脱 離とホール電荷の補償による純有機単成分伝導体の構築と その圧力下金属状態の実現, (2) 量子スピン液体状態を示 
す純有機結晶の開発，（3）有機結晶において重水素移動と カップルした $\pi$ 電子移動による伝導性および磁性の切り替 え現象の発現と $185 \mathrm{~K}$ にも及゙巨大な重水素効果を紹介し た。

実際，水素原子は $\pi$ 電子より約 1840 倍重く, 重水素は その倍で約 3670 倍も質量が異なるが，水素および重水素の 水素結合を中心として，ヤジロベエのように連動する $\pi$ 電 子系を左右に連結させて, 対称的な水素結合ユニットを有 機分子で構築すると, このような協奏系を開発することが 可能であることを示した。

今後さらに， $\pi$ 電子と水素が協奏する物質系を広げて，両 者の協奏効果への理解を深めることは，機能物性を展開す るためにも大変重要である。そして, 動的な $\pi$ 電子と水素 の協奏を相転移ばかりでなく,$\pi$ 電子伝導とプロトン伝導 の協奏に進展させることも考えられる。また, 電場や光な どの外場を印可して， $\pi$ 電子系揖よび水素系を各々制御し， 機能物性へ展開することも期待できる。

さらに有機結晶ばかりでなく，このような水素結合ユ ニット 1 個を切り出した時, また基板の上に並べて単分子 層, あるいは薄膜にした場合, 基板の性質とも相まってど のような新界面機能性がこの $\pi$ 電子一水素協奏系で出現す るのかを調べるのは興味深い。

また, 今回 $\pi$ 電子一水素協奏系有機分子の設計は, 光合 成の PSII システムにおけるキノンプールでのキノンーヒド ロキノン反応に倣った。生物は，30 億年も前から，太陽工 ネルギーから化学エネルギーへ変換する際, 分子レベルで $\pi$ 電子と水素イオンであるプロトンとの協奏反応を利用し ている。このように，有機機能性物質開発において，生体 系物質はアイディアの宝庫であり，学ぶことは無限にある と感じている。

このように，研究を進化させるためには，自分自身の フィールドに留まらず，異分野との交流がますます重要に なると思う。自分の研究に軸足を持ちながら, 他分野の研 究を取り入れていく好奇心と柔軟性, および広い視野を若 いうちから養うことも大切であると思う。

本研究のきっかけは，恩師である丸山有成教授（元お茶 大教授, 分子研名誉教授) の元で, 大学院生として分子研 で研究していた時代にさかのぼる。当時, 分子研におられ た齋藤軍治教授（京大名誉教授，現名城大学教授）の $\pi$ 電 子移動一プロトン移動共存系分子性錯体 ${ }^{43}$ が発展して, 分 子研では, 中筋一弘教授（阪大，福井工大名誉教授）が $\lceil$ PET (Cooperative proton-electron transfer)」を提唱して物質 開発を進められ，三谷洋興教授（北陸先端大名誉教授）が 物性物理の立場から，キンヒドロンの高圧下の光学測定で, 「プロトン格子の融解」の研究を展開しておられた。筆者も その後, 東大物性研の齋藤研のスタッフとして，お世話に なっていた時期に，キンヒドロン誘導体の単結晶育成に係 わらせていただいた。また海外でも，フランスの Angers 大
の Batail 教授, Avarvari 教授, Rennes 第 1 大の Fourmigué 教 授が，水素結合系分子性導体を精力的に進めておられ， 2012 年に筆者が客員教授として滞在した際，議論をさせて いただいた ${ }^{22}$ 。そして，大学院時代から四半世紀後，分子 分極が効いた分子性導体開発の途上で，分野の夢でもある 動的 $\pi$ 電子一水素協奏系分子機能性研究が進展したのは幸 いで，今後さらに発展させていきたいと思う。

本研究は, 文部科学省科学研究費補助金の新学術領域研究 (No 20110007），(独）日本学術振興会基盤研究費（No. 24340074 , 26610096)，矢崎財団，三菱財団の支援を受けて行われた。また， この研究は, 森研の上田 顕助教（ISSP）, 高橋一志元助教（現神 戸大学准教授）と森研大学院生の加茂博道氏，李相哲博士，吉田 順哉氏，参考文献に挙げた意欲あふれるメンバーと共に行われて いる。また，磯野貴之博士（NIMS），宇治進也教授（NIMS），中 尾朗子准教授 (CROSS)，小林賢介博士（KEK），熊井玲児教授 (KEK-PF), 中尾裕則准教授 (KEK-PF), 村上洋一教授 (KEK-PF), 山本 薰准教授 (岡山理科大学), 西尾 豊教授 (東邦大理) との共 同研究で，心より感謝申し上げます。

\section{参考文献}

（1）分子性機能物質, 特に分子性導体分野の発展は以下および (2) - (4)の特集号を参照されたい。Special Issue: Molecular Conductors; Ouahab, L.; Mori, T., Eds.; Eur. J. Inorg. Chem. 2014, $3780-4038$.

(2) Special Issue: Molecular Conductors; Kato R., Ed.; Crystals 2012, $2,43-1513$

(3) Special Topics: Organic Conductors; Kagoshima, S.; Kanoda, K.; Mori, T. Eds.; J. Phys. Soc. Jpn. 2006, 75, 051001-051016.

(4) Molecular Conductors; Batail, P. Ed.; Chem. Rev. 2004, 104, 4887-5782.

(5) Kimura, S.; Maejima, T.; Suzuki, H.; Chiba, R.; Mori, H.; Kawamoto, T.; Mori, T.; Moriyama, H.; Nishio, Y.; Kajita, K. Chem. Commun. 2004, 2454-2455.

(6) Kimura, S.; Suzuki, H.; Maejima, T.; Mori, H.; Yamaura, J.; Kakiuchi, T.; Sawa, H.; Moriyama, H. J. Am. Chem. Soc. 2006, $128,1456-1457$.

(7) Niizeki, S.; Yoshikane, F.; Kohno, K.; Takahashi, K.; Mori, H.; Bando, Y.; Kawamoto, T.; Mori, T. J. Phys. Soc. Jpn. 2008, 77, 073710 (1-4).

(8) Morinaka, N.; Takahashi, K.; Chiba, R.; Yoshikane, F.; Niizeki, S.; Tanaka, M.; Yakushi, K.; Koeda, M.; Hedo, M.; Fujiwara, T.; Uwatoko, Y.; Nishio, Y.; Kajita, K.; Mori, H. Phys. Rev. B 2009, $80,092508(1-4)$.

(9) Sawano, F.; Terasaki, I.; Mori, H.; Mori, T.; Watanabe, M.; Ikeda, N.; Nogami, Y.; Noda, Y. Nature 2005, 437, 522-524.

(10) Lee, S.; Ueda, A.; Kamo, H.; Takahashi, K.; Uruichi, M.; Yamamoto, K.; Yakushi, K.; Nakao, A.; Kumai, R.; Kobayashi, K.; Nakao, H.; Murakami, Y.; Mori, H. Chem. Commun. 2012 , $48,8673-8675$.

(11) Kamo, H.; Ueda, A.; Isono, T.; Takahashi, K.; Mori, H. Tetrahedron Lett. 2012, 53, 4385-4388.

(12) Isono, T.; Kamo, H.; Ueda, A.; Takahashi, K.; Nakao, A.; Kumai, R.; Nakao, H.; Kobayashi, K.; Murakami, Y.; Mori, H. Nature 
Commun. 2013, 4, 1344 (1-6).

(13) 森初果, 上田顕, 化学 2013, 68(8), 64-65.

(14) Lee, S.; Ueda, A.; Nakao, A.; Kumai, R.; Nakao, H.; Murakami, Y.; Mori, H. Chem. Eur. J. 2014, 20, 1-10.

（15）森初果，工業材料 2014, 62(1), 26-27.

（16）森初果, 上田顕, 磯野貴之, 固体物理 2014, 49, 149-160.

(17) Yoshida, J.; Ueda, A.; Nakao, A.; Kumai, R.; Nakao, H.; Murakami, Y.; Mori, H. Chem. Comuun. 2014, 55, $15557-$ 15560.

(18) Isono, T.; Kamo, H.; Ueda, A.; Takahashi, K.; Kimata, M.; Tajima, H.; Tsuchiya, S.; Terashima, T.; Uji, S.; Mori, H. Phys. Rev. Lett. 2014, 112, 177201

(19) Ueda, A.; Yamada, S.; Isono, T.; Kamo, H.; Nakao, A.; Kumai, R.; Nakao, H.; Murakami, Y.; Yamamoto, K.; Nishio, Y.; Mori, H. J. Am. Chem. Soc. 2014, 136(34), 12184-12192.

(20) Baranov, A. I.; Shuvalov, L. A.; Shchagina, N. M. JETP Lett. 1982, 36, 459-462.

(21) Hayashi, S.; Mizuno, M. Solid State Ionics 2004, 171, 289-293.

(22) 水素結合系有機伝導体の先駆的な研究は数多くあり, 総説 は例えば以下と (23)である。Fourmigué, M.; Batail, P. Chem. Rev. 2004, 104, 5379-5418.

(23) Morita, Y.; Murata, T.; Nakasuji, K. Bull. Chem. Soc. Jpn. 2013, 86, 183-197.

（24）高圧下，キンヒドロンのプロトン格子の融解およびキンヒ ドロン誘導体についての論文は以下と (25)である。 Mitani, T.; Saito, G.; Urayama-Mori, H. Phys. Rev. Lett. 1988, 60, 2299-2302.

(25) Nakasuji, K.; Sugiura, K.; Kitagawa, T.; Toyoda, J.; Okamoto, H.; Okaniwa, K.; Mitani, T.; Yamamoto, H.; Murata, I.; Kawamoto, A.; Tanaka, J. J. Am. Chem. Soc. 1991, 113, 1862-1864.

(26) Novak, A. Struct. Bondings 1974, 18, 177-216.

(27) Jeffrey, G. A. In An Introduction to Hydrogen Bonding; W. A. Benjamin Inc.: New York, 1968.

(28) Ichikawa, M. Acta Crystallogr. B 1978, 34, 2074-2080.
(29) Robertson, J. M.; Ubbelohde, A. R. Proc. R. Soc. Lond. A 1939, 170, 222-240.

(30) Moritomo, Y.; Tokura, Y.; Nagaosa, N.; Suzuki, T.; Kumagai, K. Phys. Rev. Lett. 1993, 71, 2833-2836.

(31) Ichikawa, M. Chem. Phys. Lett. 1981, 79, 583-587.

(32) Cordes, A. W.; Haddon, R. C.; Oakley, R. T.; Schneemeyer, L. F.; Waszczak, J. V.; Young, K. M.; Zimmerman, M. M. J. Am. Chem. Soc. 1991, 113, 582-588.

(33) Mailman, A.; Winter, S. M.; Yu, X.; Robertson, C. M.; Yong, W.; Tse, J. S.; Secco, R. A.; Liu, Z.; Dube, P. A.; Howard, J. A. K.; Oakley, R. T. J. Am. Chem. Soc. 2012, 134, 9886-9889.

(34) Leitch, A. A.; Lekin, K.; Winter, S. M.; Downie, L. E.; Tsuruda, H.; Tse, J. S.; Mito, M.; Desgreniers, S.; Dube, P. A.; Zhang, S.; Liu, Q.; Jin, C.; Ohishi, Y.; Oakley, R. T. J. Am. Chem. Soc. 2011, 133, 6051-6060.

(35) Neilands, O.; Tilika, V.; Sudmale, I.; Grigorjeva, I.; Edzina, A.; Fonavs, E.; Muzikante, I. Adv. Mater. Opt. Electron. 1997, 7, $39-43$.

(36) Mandal, S. K.; Samanta, S.; Itkis, M. E.; Jensen, D. W.; Reed, R. W.; Oakley, R. T.; Tham, F. S.; Donnadieu, B.; Haddon, R. C. J. Am. Chem. Soc. 2006, 128, 1982-1994.

(37) Anderson, P. W. Mat. Res. Bull. 1973, 8, 153-160.

(38) Anderson, P. W. Science 1987, 235, 1196-1198.

(39) Shimizu, Y.; Miyagawa, K.; Kanoda, K.; Maesato, M.; Saito, G.; Phys. Rev. Lett. 2003, 91, 107001 (1-4).

(40) Tamura, M.; Kato, R. J. Phys., Condens. Matter. 2002, 7, L729L734.

(41) Kanoda, K.; Kato, R. Ann. Rev. 2011, 2, 167-188.

(42) Tsumuraya, T.; Seo, H.; Kato, R.; Miyazaki, T. Phys. Rev. B 2015, 92, $035102(1-9)$.

(43) Matsunaga, Y.; Saito, G.; Bull. Chem. Soc. Jpn. 1972, 45, $963-$ 964.

（受理日 2015 年 8 月 4 日）

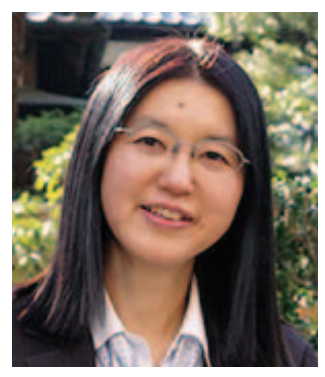

森 初果（もり はつみ）

所属: 東京大学物性研究所

専門分野：分子性固体科学

連絡先：干 277-8581 千葉県柏市柏の葉 5-1-5

電子メール：hmori@issp.u-tokyo.ac.jp

URL : http://hmori.issp.u-tokyo.ac.jp/ 